\title{
Sensemaking Revisited
}

Holt, Robin; Cornelissen, Joep

Document Version

Accepted author manuscript

Published in:

Management Learning

DOI:

10.1177/1350507613486422

Publication date:

2014

License

Unspecified

Citation for published version (APA):

Holt, R., \& Cornelissen, J. (2014). Sensemaking Revisited. Management Learning, 45(5), 525-539.

https://doi.org/10.1177/1350507613486422

Link to publication in CBS Research Portal

\section{General rights}

Copyright and moral rights for the publications made accessible in the public portal are retained by the authors and/or other copyright owners and it is a condition of accessing publications that users recognise and abide by the legal requirements associated with these rights.

Take down policy

If you believe that this document breaches copyright please contact us (research.lib@cbs.dk) providing details, and we will remove access to the work immediately and investigate your claim. 


\section{Sensemaking Revisited}

Robin Holt and Joep Cornelissen

Journal article (Post print version)

CITE: Sensemaking Revisited. / Holt, Robin; Cornelissen, Joep. In: Management Learning, Vol. 45, No. 5, 2014, р. 525-539.

DOI: 10.1177/1350507613486422

Uploaded to Research@CBS: December २०16 


\section{Sensemaking revisited}

We critique and extend theory on organizational sensemaking around three themes. First we investigate sense arising non-productively and so beyond any instrumental relationship with things; second we consider how sense is experienced through mood as well as our cognitive skills of manipulation based on standard categories, frames or narratives; and third we consider sense being governed by exposure to unknown possibility rather than retrospective assessment. We set these themes in the context of the work of Heidegger, and discuss the implications of our theorization for further sensemaking research by revisiting Weick's seminal reading of Norman MacLean's book surrounding the tragic events of a 1949 forest fire at Mann Gulch, USA.

Key words: sensemaking, process theory, framing, phenomenology, mood, Heidegger, Weick 
As a theory, sensemaking delineates the process by which organizational situations are framed, narrated or categorized through the words or bodily gestures of agents-in-contexts, and how these structure subsequent perceptions. Through experience this structuring becomes learning as agents cognitively detect regularities amid raw and often messy experience and compress these into less detailed conceptual structures that can then come to guide senses, inferences and behavior. To make sense involves contextualising a particular cue or experience in the context of a learnt frame, narrative or category, as the conceptual template, which then produces and enables interpretation (Weick, 1995: 109-110). For example, a series of articles on strategic change at a public university (Gioia et al., 1994) investigated the importance of frames and framing in top managers' speech as a way of directing stakeholders in their sensemaking of strategic change. Relatedly, Lüscher and Lewis (2008) studied ways in which managers reframed issues that surfaced because of a major restructuring in their organizations, allowing them to recover sense from what was initially a messy and paradoxical situation. Other studies have highlighted the use of plotted narratives (e.g., Abolafia, 2010; Balogun \& Johnson, 2004; Brown et al, 2012; Maitlis, 2005; Robichaud et al., 2004). Maitlis (2005), for instance, highlighted the significance of narrative accounts in both senior managers' sensegiving and employee sensemaking about events surrounding strategic change in three British symphony orchestras. In another set of well-known studies, Weick and his colleagues have studied the use and impact of socially shared codes and conventions on the sensemaking and sensegiving of individuals in tightly coupled social systems such as flight deck teams and cardiac surgery teams (Weick \& Sutcliffe, 2007). 
An important characteristic of such categories, narratives or frames is that, as socially learnt structures of reference, they impart organization, and do so largely habitually and unconsciously. Because they are habitual, the frames, narratives or categories are often latent or invisible, only surfacing in the wake of a breakdown between their long-standing utility and new, surprising experience. Hence many sensemaking studies concentrate on these breakdowns when frames, narratives and categories become apparent in the struggle to cope. For example, Weick in his reanalysis of the explosion at Union Carbide in Bhopal (1988) found the initial framing of leaking gas at the methyl isocyanate (MIC) plant to be 'a factory that's stopped'. Whilst this frame did not tally with what workers' were experiencing, it persisted amongst decision makers with disastrous effects as leak lead to explosion. Similarly, Snook's (2000) study of a 'friendly fire' shooting in Iraq finds that the framing of 'hits there' in a no-fly zone cued a response of that led to the 'friendly fire' shooting of two helicopters and their passengers. Activating a category, narrative or frame, as acts of sensemaking, thus creates expectations about important aspects of situations by directing agents to elaborate on the default or prototypical scenario in ways suggested by the frame, narrative or category. And where these suggestions belie experience, agents find their sense of experience going awry requiring a form of unlearning as habitual frames, narratives or categories are found wanting, are revised, or even replaced.

Now well established as a theory, we wish in this essay to examine whether sensemaking has become its own habituated frame, category and narrative and whether, in being so, sensemaking studies are ignoring or discounting experiences of sensemaking in ordinary organizational life. At the outset, it is worth highlighting that we engage with sensemaking theory as whole. We review the theoretical 
underpinnings of sensemaking literature and suggest the presence of a framing that confines sense to being practically desirable, cognitively expressed, and largely retrospectively organized (sense is recovered). The practical desirability of sense is espoused in the idea of high reliability organization; to make sense is to better organize things for our own ends (Weick, 1979); sense in other words is intimate with instrumental effectiveness (March, 2010: 16). The association of sense and cognitive expression comes with the predominating unit of analysis being agents enlisting linguistic, embodied and cognitive capacities in order to consciously bring about an envisaged state of affairs (Clarke \& Cornelissen, 2010). The retrospective nature of sense suggests a threefold movement: agents experiencing messy, or opaque conditions, having to enact new meanings (Colville et al, 212), before once again finding themselves uncertain, requiring yet more sensemaking.

We investigate each of these themes and theorize whether a more exposed, less anthropocentric sense of our relationship with the world can expand the criteria by which sense is acknowledged. To do so we reach for the phenomenological work of Martin Heidegger. We argue that implicitly (or in Weick's case, of late, more explicitly) sensemaking theory is grounded in the spirit of Heideggerian phenomenology (Sandberg and Tsoukas, 2011; Zundel and Kokkalis, 2010). Like advocates of organizational sensemaking, Heidegger recognizes that our relationship with the everyday world is one of unquestioned habit into which we are thrown, and making sense of this hurly burly occurs from within already institutionalized orders, primarily the grammars, standards and skills associated with everyday and shared use of language. But Heidegger shows sense extending beyond such habituated framing (and its technical or theoretical recovery) in three ways. First, sense is found within disruption itself. The temporal experience of 
rupture, shock and the struggle for re-alignment is both a breakdown but also an awareness of a world being not readily available for us, but still there, and still present to our senses somehow. Second, we often find ourselves feeling lost amid the habits, assumptions and generalities of established frames, categories and narratives without the prompt of a breakdown. Our usual frames no longer pertain when, for example, we are bored, or anxious, or in awe. Here, without any explicit cause like an accident, we experience a discrepancy, an out-of-jointness, between the public unfolding of life - the everyday of the undifferentiated, public interpretations which give sense to our activities and the passions and goals we and everyone else pursue - and our life being most real when experienced in the raw, when we are attuned to this discrepancy so that all other concerns are displaced. Third, sense arises from experiencing life projects as inherently open, without specific direction or even form, and from such openness transformative meaning might arise.

Heidegger suggests ways of expanding the criteria of sense (towards noninstrumental engagement, mood, and openness). Sense, then, extends into the very feelings of dislocation, uneasiness and exposure that sensemaking theory tends to discount or regard as a breakdown of sense. Yet through non-instrumental engagement, mood and openness frames, narratives and categories can be bent, or blended anew, giving rise to new emergent meanings that have practical import, a source of transforming change that sensemaking theory has typically struggled to explain (Geiger, 2009; Cornelissen \& Clarke, 2010; Barry and Meisiek, 2010; Munro and Huber, 2012). Whilst this essay uses many sensemaking studies to illustrate the argument, emphasis is given to the seminal categories and narrative by which sensemaking theory is framed: Weick's reading of events at Mann Gulch. In reading 
this study anew, we suggest sensemaking theory might enrich its own sense of sense.

The limits of sensemaking: a seminal case

Investigating how we learn to make sense of experience begins with what typically goes un-noticed, the habits of language and action in everyday life. If these were subject to conscious deliberation we would always be pausing, and never doing: when saying something words, grammar and phonemes silently cohere; when making something the tools and raw materials are subsumed into concerns for the final form; when going somewhere the means of mobility dovetail invisibly toward the destination. Sensemaking theory, then, begins by investigating where the invisible coherence becomes visible, in particular in spectacular breakdowns. It is within the abnormal that the habitual struggles and becomes open to view. Emergencies reveal the contrast between how past organization has corralled language and behaviour to order our relations with the world, and how, through breakdown, new forms of organizing might arise as agents cope in novel or complex conditions for which their typical repertoire of sensemaking behaviour (the frames, narratives and concepts used to distill phenomena into meaningful classes) are inadequate (Weick, 1988, 1993).

The classic study of breakdown is offered in Weick's (1993) re-analysis of the organized attempt in 1949 to fight a forest fire at Mann Gulch, Montana, USA. Flying over the fire, 'spotters' called it a "10 o'clock fire", and as they jumped with their equipment into this remote region, the firefighters had already activated a frame of a fire that would be contained by 10 the next day. Once on the ground, they enacted 
this frame through routine acts such as walking the opposite side of the gulch (valley) to approach the main fire from its flank. A few hours in, their foreman Wagner Dodge noticed a 'spot fire' that had leapt the river in the gulch bottom, and fanned by the strong headwind was coming toward them. With the main fire still raging on the other side of the gulch, this 'spot fire' became a 'blow up', spreading from a few to thousands of acres in a matter of minutes. The fire began to resist its framing as 'a 10 o'clock' type. Dodge ordered his team up the slope, then, noticing the fire still gaining, he shifted to an alternative frame, shouting for them to drop their tools so they might move more quickly. Finding the fire inescapable he stopped and lit round himself what became known as an 'escape' fire: crouching in the blackened clearing, the larger, hotter fire was forced around rather than over his prostrate body. His crew, however, had rationalized the earlier frame and did not shift their thinking, in part, according to Weick, because they were unable to extract themselves from the habits of being 'firefighters'. The recovery and ultimately their survival demanded inquiry into their immediate experience of the fire that was too transformative to contemplate; dropping tools and lighting fires was not what they did; rather they used tools to put fires out (Weick, 1993, 1996). Dodge and two others survived, 13 of their colleagues died.

Weick's analysis of events at Mann Gulch explores how sense emerged from successive attempts at restoring order; an ongoing, retrospective, organized activity of calling up and using plausible images (categories, frames, narratives) that rationalize events so as to better organize controlling activities. Weick concludes that less stringent commitment to frames and tools may have enabled the firefighters to shift their thinking and to adapt and improvise in real-time. Weick makes the sensemaking processes of the firefighters apparent, discovers fragilities, then 
generalizes to other organizational conditions to make present what can be learnt from the case.

In this Weick is recognizing that we relate to the things of the world as extensions of ourselves, understanding ourselves primarily as active, not contemplative beings, whose activity is synonymous with technical manipulation and ordering, of making things with things, including facts (from facere, to do or make). Such sense is organizational; the relational ordering of life through processes that were first ingenious, then useful and finally habitual ways of meeting pragmatic needs. Hence Weick's concern with the ways in which the tools and identities of firefighters objectified their response and the identity of the fire they were facing.

This concern is taken up in another case of breakdown used in sensemaking theory: the lead up to the launch of the Columbia space shuttle and NASA's use of the code 'in-family'. When a burst of debris was observed at the root of the left wing of the space shuttle, which was observed 82 seconds into the launch, it was interpreted as 'in-family' (Weick \& Sutcliffe, 2007). This code signified a general and institutionalized frame or category of anomalies or cues being classed as "in-family" versus "out-of-family"; a language that NASA managers and engineers had been socialized into using to designate "a reportable problem that was [either] previously experienced, analyzed and understood" (Weick, 2005: 168), or not. The ease with which this code was used meant that risks and unexpected cues in the form of a burst of debris were incorrectly categorized as largely understood and under control (Ocasio, 2005; Weick \& Sutcliffe, 2007). Once the code had been activated it did not simply trigger or prompt the retrieval of expectations and a framed trajectory from memory but, as in the Mann Gulch case and the use '10 o'clock fire', fabricated the very nature of such expectations. 
This link between sense, organization and tools is made more overt by Weick's placing sensemaking capacity within the basic phenomenological struggle to organize experience as a form of technical and controlling craft (technē). To make sense is an embodied effort (verbal and activity) involving abducting between events and models, plotting narratives and selectively retaining those interpretations considered valuable or preferable (Abolafia, 2010). Cognition reaches after stability: experience is appreciated through cues that find frames, to which we are then able to add predicates, resting ourselves in the conceptual array by which our experience is organized with others, collectively and historically. Narrative is often used, allowing agents faced with breaches in conventional understanding to construct an account of events rapidly and under pressure by calling up a limited number of actors whose actions and dispositions can be reasonably ascribed causal power within limited time and space. In the case of United Airlines Flight 93 (Quinn and Worline, 2008), for instance, it enabled collectively courageous action.

Sensemaking is sensitive to human agency being distinct in its capacity to assess and select stimuli, to make different readings of the past accord with present demands, and so find history a repository of meanings that can be brought into service when experiencing disruption (Emirbayer and Mische, 1998), not only in the immediate setting (the firefighters run to evade the fire, managers and engineers drop 'in family' framings, under threat passengers cohere) but through analysis of the aftermath. Thus arising from analysis of events at Mann Gulch or NASA or Flight 93 come new modes of organizing associated with revised safety procedures and training methods and new tools.

Weick dissolves the pretense that this struggle of technē is heroic, definitive, or blazingly transformative; he recognizes it as a re-folding of experience, theory and 
habit that furtively, haphazardly even, reaches for recovery. He is also mindful of the fragility of technē. For example, he describes the collapse of both sense and the structural means to restore sense experienced by the Mann Gulch firefighters as a 'cosmology episode', a fundamental realization that the world is no longer an orderly, amenable, or even graspable place. What concerns him is evaluative; to learn from breakdowns we must become increasingly ambivalent about our capacity to control events through organization, and instead plan for surprise in organizational life in ways that were not open to, or opened by, the firefighters. The pragmatic job of sensemaking is to prevent breakdown by learning how our frames, narratives and concepts can restrict understanding and skilful engagement as much as afford them; organization is its own source of disruption.

A breakdown is identified (the panic and structural malaise of a cosmology episode) out of which "vantage point" (Weick, 2003: 468) lessons are learnt. The evaluative response from sensemaking theorists is of the kind: develop more nuanced framing or coding language allowing you to make sense as events unfold rather than rely on simplifying abstractions; distinguish and learn from failures, for therein lie sources of great insight; favour the complexity of operations above the simplicities of strategy; organize for resilience rather than assume predictability of circumstance; and allow expertise to speak wherever it might be located rather than have it mediated through hierarchies. The result: a high reliability organization. This is nuanced argument, asking whether learning from breakdowns should extend the reach of organization from enacting technical fixes to known problems to, in addition, creating resilience through adaptability, thereby accepting experience will always speak back, often unpredictably. Sensemaking is comfortable with brushing up to 
everyday life, studying how people embody a sense of who they are and where they are going in their everyday, coping lives (Weick, 2012).

Yet there is room for pause here. Hannah Arendt (1958: 308-309), for example, warns us that in the spread of technē (exemplified by treating breakdown cases as vantages for learning) we humans confine sense too readily to a condition of desirable instrumentality. Prompted by Arendt, we might ask whether the nuanced and provocative reading of Mann Gulch is itself a frame through which subsequent sensemaking scholars have organized studies without themselves questioning the grounding assumptions that sense is desirable (flux and opacity always are experiences to be tamed by sense) and equates to feelings of instrumental settlement (control, knowledge, flexibility). What, we might ask, of organizational experience that resists post hoc rationalization, is too nebulous to be confined to cognitive patterns, and is free of immediate instrumental implications? Is sensemaking theory really open to flux (everyday or in extremis) in the way many adherents suggest it is?

Martin Heidegger and experiencing 'Breakdown'

If sensemaking theory does not start 'raw' enough, if the claim to begin with the flux of everyday habits and upsets out of which research might distil the organizational processes governing the creation of sense is already itself framed, how else might we go? One response is found amid the work of Martin Heidegger. Though not often mentioned, save for Weick's work, Heidegger also considers how we are already and always in a world configured (framed) by our bodily interaction with and interest in it. Our typical relation to things is one of ready-to-handness 
(Zuhandenheit). Things have the status they do because they matter in our day-today affairs; they are objects, arrangements and tools we use to better situate us within the world as a world-we-make-sense of, aligned, as it is, to our interests and bodies. So to make sense of things arises from becoming more or less skillfully attuned to their potential as equipment-for-us, without any additional need for a mental representation of such (Dreyfus, 2006). This pragmatic entwinement of being (who we and other things are) with form (the shape and presence of things, though often hidden through use), material (properties), purpose (the implicit ends to which things are organized), and of ourselves as efficiating this orchestration in endless too and fro, is engrained as the un-noticed organizational ground from which judgment, options, improvements and setbacks occur.

Sensemaking theory concurs (Sandberg and Tsoukas, 2011). In spirit it also concurs -- though outside of Weick (e.g. 2012: 146; Weick and Putnam, 2006) rarely acknowledged - with Heidegger's observation that we notice this otherwise commonsense, embodied entwinement of ourselves and the world in moments of breakdown - of unreadiness-to-hand - of which Heidegger suggests there are three forms: things become conspicuous because they no longer work; things obtrude because they are missing; and things become obstinate as they block our thought or movement. In the wake of such breakdown, things stand out; they come into presence, eliciting interpretive inquiry (rationalising the breakdown experience) whereby we attempt to recover our equipmental balance.

This revealing of our embodied condition in moments of extremis finds things losing their context of use, and instead becoming abstract representations with properties, fits well with sensemaking studies. At Mann Gulch Weick (1963: 635) finds the firefighters had created and sustained a rationalization of fire as something 
dangerous, but for which they were ready (10 o'clock fire). Similarly, Vaughan's (1996) study of the Challenger Shuttle disaster shows that prior to launch, manufacturers and NASA engineers had used idiomatic expressions such as "give and take" and "go with what you've got" (Vaughan, 1996: 103). This framing had normalized risks associated with so-called O-rings meant to seal sections of the booster rockets. Just as crucial, however, was the framing by managers from a NASA contractor on the eve of the launch, when they used the idiomatic phrase "tak[ing] off [their] engineering hat and put[ting] on [their] management hat" (Vaughan, 1996: 316) to iterate between NASA's managerial frames of "planning" and launch "procedures" and the framing of their own engineers' safety concerns. The emergent inference arising from this framing was that by activating a particular vantage point, over and beyond the engineering standpoint, launch could be recommended.

In both cases the learnt habits and framing proved inadequate, leading to panic and fear as events overtook habitual understanding. Weick's analysis of Mann Gulch finds the object 'fire' being framed as ready-to-hand (as a 10 o'clock fire' or 'a family event') and then made unready because the fire is no longer working as it ought (the spot fire becomes conspicuous, separated, a prompt reminding the firefighters that they had to get a job finished, an for which their current means were becoming increasingly unavailable). The upshot is, as the firefighters run, habituated tool use blocks movement as the tools lose their context and become distinct objects with the obstinate property of weight. Likewise, Vaughan finds managerial framing preventing adequate thought (obstinate), the implication being that to recover the readiness to hand of high reliability organization procedures one needs to account for differing experts' opinions. In both cases the mis-identifications arising in 
experiences of conspicuous, obtruding or obstinate breakdowns are analyzed as a function of inadequate frames, categories and narratives that can be corrected through learning anew the coming together of sense, fabrication and organization. Zuhandenheit is recovered through a reasoned articulation of the problems encountered, coupled to the institution of new organizational forms preventing such occurrence reoccurring, albeit ever aware breakdowns of some sort will occur.

This is where sensemaking theory seems to stop, satisfied to have grasped processes of sensemaking and sensegiving as commonsensical, embodied and inherently open as we look continually to attune ourselves to a world on the move of which we remain always a substantial and dynamically engaged part. Heidegger (1951/1968: 34), however, carries on, pressing inquiry behind the reasoned identification of and recovery from episodic breakdown, to ask, first, whether things (including ourselves) can be made sense of other than as equipment (actual or potential) and, second, whether we might be aware of the world differently from it being "a calculable coherence of forces" set forth through the understanding (Verstehen) and talk (Rede) of language? Can we, in addition, make sense through non-productive (and not only unready-to-hand) relations with things (Harr, 1993: 24, 27; Heidegger, 1954/2004: 41-44; Zundel, 2012)? Heidegger (1978/1979: 34) says yes, through what he calls attunement (Stimmung), a kind of harmonious jointfrequency where sense is no longer swallowed up by understanding and talk. Sensemaking limits its concerns with the two vectors of being Heidegger labels understanding and talk, within which something like fire is always becoming something else (say a 10 o'clock fire), separated from experience (using frames etc.). Heidegger suggests a third vector, attunement, which loosens such separation. 
During the early 1950's Heidegger was undergoing a difficult rehabilitation into social and scholarly life in the lingering aftermath of his disastrous affiliations with the officialdom of Germany's Third Reich, notably as Rector of Freiburg University. He himself was beginning again, now writing in plain tongue, his texts beguiling, primitive considerations of what it was 'to be', with little political or organized adornment. In An Introduction to Metaphysics (a course of lectures originally given in 1935 immediately after his resignation as Rector of Freiburg but re-written for publication in 1953) he begins by asking: "Why are there essents, rather than nothing?" This is where phenomenological inquiry might start because it is the widest of all questions, covering all possible events and reaching an end only when events stop and there is nothing. It is also the deepest of all questions, reaching to the grounding of all things; and it is the most basic of questions, because we are distanced from any specific thing or event, all of which become equal (Heidegger, 1953/1959: 2-4). Inquiry, and hence theory, too often ignores the 'nothing' part of the question. Considering nothing, or absence, is not so much a concern with emptiness as an awareness that things can always be otherwise, or not be at all (Heidegger, 1927/1962: §70; 1953/1959: 27). To ask of things what they are is only half an inquiry - the stipulation of presence, of substance, confining sense to something cumulative and documented, as though through learning and scribing with representations we accrue ever more awareness, we progress, when an integral aspect of our sensemaking comes with contrast with absence, a curiosity with decay and endings.

Turned on our own being as humans, this concern with nothing throws up a further realm of sense. Heidegger describes our already organized condition as being fallen (Verfallenheit). The term evokes how, being thrown into the world, we 
find ourselves absorbed by our exposure to the prevailing discourses and habits of public everydayness; our language being the property of das Man, of everyone, and hence of no-one. Within the leavening influence of this public grammar (platitudes, time-worn mores, instruction, and our constant curiosity for the 'new', etc.) we still, occasionally, feel equivocation, even tension. Such tension requires no breakdown in the organization of our lives, but emerges when that organization itself becomes vacuous and pointless.

Heidegger suggests this arises because our experience of Verfallenheit is accompanied by a temporal or directed sense of existence. A discrepancy arises between the timeless demands and pleasures of a public unfolding of life - the everyday organization of the undifferentiated, public interpretations given to activities, passions, goals - and a sense of life as 'our own'; as something we alone experience and that is finite, so that our experiences take on a unique importance. This mine-ness (Jemeinigkeit) is not that of an inner cogito lying behind actions, but awareness of the impossibility of considering being without personal pronouns: ‘ am', 'you are'. Life is, as Heidegger (1988/1999: 37-39; 63) insists, always mine, and yet this mineness finds itself constantly dispersed, split up and fallen into a world that is precisely not 'mine' but everyone's and which is all there is, so that my possibilities of becoming who I am are continually averaged out to fit the frames and sensibilities of das Man, we are always and forever dispersed through organization.

This out-of-joint feeling between a sense of mine-ness and its inevitable public dispersal through organization is, for Heidegger, experienced through mood. Typically we understand moods as fleeting, momentary disruptions to our pragmatically embroiled everyday lives. Moods are often considered things to be avoided; their declaration a badge of weakness, symptoms of breakdown even. Yet, 
for Heidegger, moods are an unavoidable and primary aspect of us being 'there', dwelling amidst others and otherness. Only because we are always already attuned to the world can any cognitive rationalization occur. Moods first connect us with our world and therefore indicate things at their most nascent, equivocal things-inthemselves rather than objects of definition (Staehler, 2007). Many moods have direction (we resent something, we love someone), yet certain moods occur without such tethers, moods of boredom, anxiety, awe, and wonder, for example. These are the moods (Stimmung) that interest Heidegger as they can attune (stimmen or tuning) us to something of ourselves of which we are not the foundation and yet which remains with us. They arise without object, indicating our connection with the world directly, displacing the framing, narratives and concepts characteristic of the other two vectors of being in the world, understanding and talk. Our frames and cognitive patterns become idle, useless, and we remain puzzled, unable to respond by suggesting fixes, and to the extent we do restart them, the mood dissipates. The affect is uncanniness because in spite of this nullity experience endures and so it itself is a possibility, outside of any worldly or pragmatic possibility. It is the very emptiness that startles us, because in spite of the complete absence of grounding within das Man we continue to exist, our life is ours, and that which is most real. Moods leave us open, suspended between not being able to leave a place but not being able to remain captured, or habitually absorbed, either. In mood the concealed nature of the world (felt as alienating, uncommunicative overwhelming) reveals itself. Things exist, but in boredom they do not occupy us, in awe they overwhelm us, in anxiety they refuse to anchor us. We are left in suspense. It is here we may experience a clearing, an opening between ourselves and the world that we glance a world existing but refusing any specific frame (it is not speaking to our interests), yet 
it is still revealed, and hence appears to us as a source of pure possibility, we are aware everything being withheld, announcing the inactive possibility of a world lying fallow (Brachliegen), a clearing, unused, without purpose (Agamben, 2004: 70-74).

In such moods life is lived on the cusp of its own dissolution, its being nothing that can be stated, or classified, or named, but which is there and which vibrates, or shimmers, or bristles, with concealed possibilities. This is where we become aware of the question of nothing. Our tendency is to repress this feeling, to expunge it, to confront it busily trying to alleviate the impress of vacancy by making sense, whereas Heidegger wishes we might steward it as a source of possible but unknowable transformation. This insight is momentary; it reveals a world in all its perilous potential in a mere glance of the eye (Augenblick), out of which expression we realize our own complicity with the world as being our world, something we make by being in intimate, sensible, corporeal relations with it, rather than through rational choice (Strati, 2007; Zundel, 2012). So this freedom and making, though, is not about our individual will (or its organized control), but a reticence, a refusal to readily organize, a resistance to the sublimating tendency to always want to state and know things and to measure all our experience against this experience of knowing (see Cavell, 1969/2002: xxxv). Reticence is a relational not cognitive condition, brought about when Verfallenheit is felt as something uncanny. Mood exposes us to a world that is not there simply for our own satisfactions. Being so attuned finds us aware of ourselves as persisting in spite of an 'indifferent' world and hence open to a gathering of transforming influence and enterprise as we encounter the historical task of having to produce and reproduce ourselves (Staehler, 2007; Held, 2006). As pure possibility, this attunement can only be future oriented; in mood we are held open. We experience how our projects can only ever be led in draft-form rather than 
fulfilled, because all ends are superseded, all organization is ongoing and nothing completes (Safranski, 1998: 350).

Extending sense

Our brief foray into Heidegger finds perceptual capacities given a conceptual framing that however remains steeped in how non-linguistic, non-reasoned experience is structured. Sense emerges: first, from awareness of what is absent or concealed as much as what is present or revealed as a means (equipment) to an end (interests); second, from ruptures to habit that cannot be described as breakdowns in well-established cognitive patterns, but experienced through mood; and third, from an exposure to an open, unknowable awareness of future possibility. These three entwined threads of making sense (absence, mood and being open) disrupt what we have argued is a tendency amongst sensemaking studies to limit awareness of how sense emerges to: the on-going organization of instrumental means and ends by which the world is made ready-to-hand, cognitive behaviours, and retrospective assessment. Using Mann Gulch (supported by reference to other sensemaking studies), we now unfold each of these points in turn. .Our overall aim here is to suggest, in a counter-factual manner, alternative ways of understanding and exploring 'sense' and beyond the established ways in which sense has been conceptualized within the larger body of sensemaking research.

\section{Absence}

The fire at Mann Gulch is, according to Weick's analysis, framed (made present), inadequately, as a ' 10 o'clock fire', as was the subsequent identification of 
the 'spot fire' that outgrew its moniker. The presence of the fire as fact (the fire 'is') or in habit (woven into enacted, learnt routines) does not remain continuous, it morphs, making the breakdown both conspicuous and obstinate; it disrupts its own framing and categorization as it threatens survival, finding the prosthetic arrangements of firefighter-tool-environment wanting in some fundamental way. This 'cosmology episode' has temporal duration, fear abounds as what was known 'as' something (the type of fire) and habituated within skilful sensitivity to fabricating practice (technē) loosens its presence. Firefighters (except Dodge) simply run away from the engulfing smoke, heat and flames. The world overcomes them, most die, but not before they are stripped of their habituated expectations, their constructed identity, and their craft. The 'cosmology episode' arises because they experience danger, they are alone, in fear, emptied of cohesion. The story is written and read didactically: "How can organizational resilience be created that allows us to cope even in such extremis?" leading Weick (1993) to answer by suggesting we learn new forms of framing and cognitive behaviour: improvization (Dodge's life-saving, instinctual escape fire); create virtual roles (imagine 'ways out' of any scenario beforehand); be wise (awareness that in withdrawing to observe reality, the focus gained is both a condition of knowledge (clarity) and ignorance (narrowness)); encourage face to face interaction (the two other survivors acted at each other's behest, squeezing into a crevice).

Through learning we recover the readiness-to-hand of things by acknowledging the seductions of our frames, categories and narratives that find us thinking events are one way, when they are another (we learn to distrust our 'knowledge that'). We also learn to alter our tool using habits to cope with the unexpected (we learn to alter our 'knowing how'). Yet in making such readiness-to- 
hand explicit, the way is also open for envisaging, or imaging, less instrumental relationships with things. Things like the fire and tools lose obvious status, becoming less like objects and more akin to things with possibility (Heidegger, 1962: 102-104).

Thus sensemaking theorists might ask with regard to Mann Gulch: "Why are there firefighters, and not nothing? Why not let fires burn out naturally?" We then become aware of how firefighting makes sense with reference to its directed end, the extinguished fire. It does not stop here though. The extinguished fire only makes sense as means to yet other organized ends, like preserving property, timber resources or wild animals, which in turn are made sensible with reference to other means associated with status, resources and biodiversity, and so on. In considering absence, then, we become alive to a pre-conceptual condition in which means-ends organization is itself open to questionability - why are there things-for-us, and not simply things?

Mood

As things slide from their typified status as 'tools', we might also consider the complete absence of use-value experienced through moods. Not any mood. The fear felt at Mann Gulch, for example, is a mood of no longer knowing one's way about; specific possibilities once found available are lost. Heidegger (1927/62: II, 68) discusses the mood of fear using the example of fire. We fear something (the coming to be of the fire), awaiting something harmful to survival and flourishing; the self is understood as a distinct object (sentient being capable of promising and hence of having a sense of its future and past) in relation to other distinct objects (source of ignition, flammable material, gasses that may threaten a future). Fear is sensed instrumentally. In contrast to fear he discusses anxiety in which there is no object 
fixation, whether it is fixed as ready to hand (as a 10 o'clock fire), or made present as breakdown (an obstinate fire), or classified as a subject of analysis (a fire analyzed and understood differently, say under different wind patterns). Anxiety arises without object, exposing us to the world as it is, as opposed to the mood of fear which we feel when we fail to find a pragmatic fit between our own sense of possibility and the possibilities offered by the world. Firefighters in the Mann Gulch moments were busy, using or dropping frames, simply running, yet their accounts afterwards reach into anxiety, the open concern with whether such experience mattered at all, once the grass and wildlife return, sheathing the fear in natural indifference.

Sensemaking studies linger with moods like fear, offering reasoned, organized correctives. Yet even here we might pause. The nature writer Nan Shepherd (1977/2011: 14) talks of such when, half immersed in a mountain loch, looking down at her submerged legs finds her next step lingering over the edge a precipitous fall into lucid depths; "The first glance down had shocked me to a heightened power of myself, in which even fear became a rare exhilaration: not that it ceased to be fear, but fear itself, so impersonal, so keenly apprehended, enlarged rather than constricted the spirit." Shepherd finds, on occasion, no such corrective is needed. Heidegger makes the same point, but he looks further still, outside of directed moods like fear of something, to objectless moods like anxiety, awe or boredom, moods typically discounted as nebulous, too vaporous to be governed in organization they bring the experience of organization itself into question. These moods are distant from the struggle to find an adaptable, appropriate 'fit' between the frames, codes and narratives of Verfallenheit (the organization of signs and standards into which we have fallen) and our experiences of equipmentality (the organization of habituated skills and rationality). Their presence indicates another, 
existential struggle by which a reticent self comes back again and again to the experience of being in possession of itself (mine-ness) whilst remaining in the thrall of das Man (Arendt, 1958: 170-172; Introna, 2009; Staehler, 2007).

How, though, to read mood into the events at Mann Gulch? Without any direct affinity to the data, one way is to consider how Weick bases his own analysis on Norman Maclean's book Young Men and Fire. Basbøll (2010) finds discontinuities between the two accounts. Maclean's, for example, talks of the firefighters being 'confident' and 'at ease' in the run up to the fire, and not at all in a state of 'panic', even with the 'blow-up' approaching, one, Navon, even taking pictures. Nor does Maclean find the firefighters stubbornly holding onto the positive illusion of it being 'a 10 o'clock fire', instead finding them revising their assessment well before it became an obstinate breakdown. Moreover, contrary to Weick, Maclean finds some of the firefighters are already wise. For example, Dodge was already breaking habit wanting to make for the river before the threat (spot fire) became acute, and some of the crew had dropped tools well before Dodge's instruction to do so (see MacLean, 1992; 70-75). Basbøll (2010) then asks why Weick presents contrary readings of Maclean's diligently researched and eloquently presented story?

What Weick offers is itself a lucid selection; narrating, in a style that has almost deceptive appeal (Rowlinson, 2004), a compelling scene into something not emphasized in Maclean. Maclean seems content with evoking a tragedy with missing parts, a story devoid of resolution or retrofitted into analytic order, aware perhaps that what Mann Gulch tells us is less about failures in maintaining organizational sense, and more about the erratic and indifferent behavior of the natural forces beyond our control (Basbøll, 2010; Whiteman and Cooper, 2011). Weick's didactic leanings offer lessons for creating high reliability organization, and events are 
isolated using loose criteria of plausibility to coalesce around these lessons. Weick is interested in comforts of recovery, in how organization might restore itself and how we readers might learn from this restoration, applying the lessons elsewhere, tightening organizational effectiveness. Maclean is interested in ordinary tragedy and the acceptance of a world whose processes and natural forces remain beyond control and conclusive framing. MacLean's account is moodier, dwelling on questions of the human spirit, in how humans sit amid a wide, indifferent and often impenetrable environment. Mood can find grip here, if it is told like this, sense without recovery; in Weick's account mood is expelled by urges to understand and talk, unable to live without explanation and lessons.

\section{Being open}

Through awareness of absence (the concealment of things by which they refuse to declare themselves as being-ready-for-us) and mood (a sense of persisting in spite of an indifferent, or overwhelming world) comes openness. Ready distinctions dissolve in un-decidedness and the sway of possibility. Heidegger talks about this as a reticence in which the calls of "acceleration, calculation and [the] claim of massiveness" (Heidegger, 1988/1999: 63-70, 83) dissolve, leaving a clearing in which there is holding open to possibility, for which there are no reasons. Being open is awareness that in encountering a world that is 'opening out' the world also "escapes human disposal" (Held, 1996: 49). There is judgment still, but it is a putting of oneself into the openness of an imageless world (Heidegger, 1988/1999: 63); neither 'knowing that' nor 'knowing how', beyond the idle chatter of das Man. There is withdrawal from decidedness, a readiness to return to the beginning again and again and so resist transformation into organized conditions, however 
momentarily. In reticence we become embroiled in questions that seek what no skill, or inventiveness or rationalization can find (Heidegger, 1954/2004: 8) because things as things (rather than things as something of significance to us) are always turning away, they withdraw and it is in this turning away we might experience transformative possibility (Heidegger, 1954/2004: 13).

Within events at Mann Gulch Dodge's activity might embody such reticence, there is immediate recovery, but without object. He 'builds' his escape fire. Building escape fires was not established practice and Dodge was unable to explain why he arrived at the idea, though explanations were demanded of him. He resists explaining, he is being pulled into a future without frames, categories or narratives, the fire and its roar had shut him out from the rest of the world, and he resists instrumentality further by then lighting a further fire. Rather than a breakdown, Dodge's experience can be reconfigured as a letting go of the conventions of Verfallenheit. Sallee, one of the survivors who'd got to the ridge and hence relative safety of the 'other side', recalls thinking Dodge "must have gone nuts' when he saw his foreman "enter his own fire and lie down in its hot ashes to let the main fire pass over him" (Maclean, 1992: 75). This is a letting go by which Dodge acts, himself, as a clearing, an open space in which new possibility emerges. Dodge creates a clearing literally, as a patch of ashes. This clearing conceals what has been (transcending his trained habit of fighting fire with tools and acquired frames of known objects like 10 o'clock fires, destroying objects such as flammable grasses) and opens up possibility from such absence (the lighting of fire without fear, to then allow fire to pass by), before again being averaged out into a uniform landscape, once the flames have swept across it. Rather than demonstrate expertise in acquired skill, Dodge momentarily allowed fire and flammable things and his own sense of 
self-productive attunement to speak without organized expression. It is just a glimpse, organization spills back in, but momentarily sense lay beyond articulated or skilled understanding, it lay beyond habit and analysis, and yet is still, inevitably, instrumentally gathered as the wellspring out of which new skills became possible (lighting 'escape fires' becomes established practice).

Conclusion and implications

Struck by the undoubted but often unacknowledged sympathy between sensemaking theory and Heidegger, we have argued that there may be more (or less?) to sense than is being currently acknowledged. In following Heidegger's often elusive investigation of how sense 'appears', we might begin by studying our habituated and means-end relationship with things, along with the practical and theoretical attempts to recover these in the wake of breakdowns, but we need not end there. Indeed, we ought not. To convey this we suggest that where sensemaking studies congregate around an instrumental, cognitively framed and retrospective awareness of sense, Heidegger's phenomenology encourages us to wander more freely, becoming aware of how sense can also arise in conditions of absence, mood and being open. Throughout we have illustrated our argument using Weick's study of events at Mann Gulch, supplemented by references to other indicative studies in the field. We have argued that Mann Gulch and its advocacy of high reliability has itself become a standard, habituated frame by which other sensemaking studies have taken their cue as to the ontological nature of 'sense'. By revisiting this seminal case we have opened up sensemaking theory to a richer vein of the appearance of 'sense' where sense appears without awareness of already existing ends. 
Our beginning point has been to reveal how, within sensemaking theory, there is a tendency to view the world as our world. Through enactment, selection and retention an instrumental view of sensemaking prevails. We approach and understand things on our terms; they are shackled to us, to our language, our interests, our qualms. This is the world Heidegger understands as equipmental (we find things as tools for our use) and fallen (we find ourselves amid the cultural and social conventions of everyone, das Man). The more organizationally adept we become, the less recourse we have for querying the sense of anything. Breakdowns are simply temporary arrests in the equipmental weave, and in turn demand innovative, organized responses. This emphasis on instrumentality explains our automatic reliance on default frames, categories and narratives that allow individuals to order and depict their circumstances (e.g., Maitlis \& Sonenshein, 2010; Weick, 1995) and to make frame-based inferences (Gioia et al., 1994), and it also explains how such frames, categories or narratives, as analogue and fixed representations, may be at the root of sensemaking failure (e.g., Snook, 2000; Vaughan, 1996; Weick, 1988, 1993, 1995; Weick \& Sutcliffe, 2007). On this reading, sensemaking conflates sense with organization; sense is what governs the condition of Verfallenheit.

This conflation is not something we can escape; we are users of tools, pragmatic people, beings with material interests in leading a life in which things are enlisted in our survival and flourishing. Yet Heidegger insists our obedience to this sensemaking condition into which we have fallen, and out of which our projects emerge, need not be blind; we can question our condition of always and already 'being organized' by asking why recovery matters, thereby "relay[ing] questioning into the same ground as necessity" (Heidegger, 1988/1989: 51). 
So what may be gained by the widening of the possibilities of making sense to include non-instrumentality, mood and being open? It is clear that the 'gains' of such learning may not be construed by effects such as recovering the stable functioning of systems like aircraft or forests. Where instrumental, cognitively expressed and retrospective sensemaking aims at preserving or reinvigorating bounded systems through new forms of organizing, we have suggested sensemaking might also bring to the fore our relationship with the world as such. From this entirety, no single relation can be abstracted, weighed, or improved, but the world in toto, (including us) is glimpsed as being out of joint, a kind of basic breakdown in the ordering of das Man from which comes the momentary possibility of lives being lived in novelty, beyond organization. 


\section{REFERENCES}

Abolafia, M. (2010) 'Narrative construction as sensemaking: How a Central Bank Thinks', Organization Studies, 31(3): 349-367

Agamben, G (2004) The open. Stanford: Stanford University Press.

Arendt, Hannah (1958) The human condition. Chicago: University of Chicago Press.

Bakken, Tore \& Hernes, Tor (2006). 'Organizing is both a verb and a noun: Weick meets Whitehead'. Organization Studies, 27(11): 1598-1616

Barry, David and Meisiek, Stefan (2010) 'Seeing more and seeing differently: Sensemaking, mindfulness, and the workarts', Organization Studies, 31(12): 1-26.

Balogun, Julia \& Johnson, Gerry. (2005) 'From intended strategy to unintended outcomes: The impact of change recipient sensemaking'. Organization Studies, 26, 1573-602.

Basbøll, Thomas (2010) 'The Moral Psychology of Organizing: From Sensemaking to Positive Organization Scholarship'. Research seminar paper, St Andrews University, March $24^{\text {th }} 2010$.

Brown, Andrew, Ainsworth, Susan \& Grant, David (2012) 'The rhetoric of institutional change' Organization Studies, 33(3): 297-321 
Cavell, Stanley (1969/2002) Must we mean what we say? Cambridge: Cambridge University Press.

Colville, Ian, Brown, Andrew, Pye, Annie (2012) Simplexity: Sensemaking, organizing and storytelling for our time', Human Relations, 65(5): 5-15

Cornelissen, Joep (2012) 'Sensemaking under pressure: The Influence of professional roles and social accountability on the creation of sense'. Organization Science, 118-137.

Cornelissen, Joep \& Clarke, Jean (2010) 'Imagining and rationalizing opportunities: Inductive reasoning, and the creation and justification of new ventures'. Academy of Management Review, 35(4): 539-557.

Emirbayer, M. and Mische, A. (1998) 'What is agency?' American Journal of Sociology, 103(4): 962-1023

Geiger, Daniel (2009) Revisiting the concept of practice: toward an argumentative understanding of practicing. Management Learning, 40(2): 129-144.

Gioia, Dennis A., Thomas, James B., Clark, S.M., \& Chittipeddi, K. (1994) 'Symbolism and strategic change in academia: The dynamics of sensemaking and influence'. Organization Science, 5: 363-383. 
Haar, Michael (1993) 'The enigma of everydayness', in J. Sallis (ed.) Reading Heidegger, Bloomington: Indiana University Press.

Heidegger, Martin. (1988/1999) Contributions to philosophy (from enowing). P Emad and K Malay (trans). Bloomington \& Indianapolis: Indiana University Press.

Heidegger, Martin (1968/1972) On time and being, Joan Stambaugh (trans). New York: Harper Row.

Heidegger, Martin (1954/2004) What is called thinking? New York: Harper Row. Heidegger, Martin (1953/1959) An introduction to metaphysics, Ralph Manheim (trans), New Haven: Yale University Press.

Heidegger, Martin (1927/1962) Being and time, J. Macquarie \& E. Robinson (trans). London: SCM Press.

Held, Klaus (2007) 'Phenomenology of 'authentic time' in Husserl and Heidegger'. International Journal of Philosophical Studies, 15(3): 327-347

Held, Klaus (1996) 'Authentic existence and the political world, A Morgan \& F 'O Murchadha (trans), Research in Phenomenology, 26(1): 38-53

Introna, Lucas (2009) 'Ethics and the speaking of things', Theory, Culture and Society, 26(4): 398-419 
Lüscher, Lotte S., \& Lewis, Marianne W. (2008) 'Organizational Change and Managerial Sensemaking: Working through Paradox'. Academy of Management Journal, 51: 221-240

Maclean, Norman (1992) Young men and fire. Chicago: University of Chicago Press.

Maitlis, Sally 'The social processes of organizational sensemaking', Academy of Management Journal, 48: 21-49.

Maitlis, Sally \& Lawrence, T. (2007) 'Triggers and Enablers in Organizations' Academy of Management Journal, 50: 57-84.

Maitlis, Sally \& Sonenshein, Scott (2010) 'Sensemaking in crisis and change: Inspiration and insights from Weick', Journal of Management Studies, 47: 551-580.

Mangham, lain \& Pye, Annie The doing of managing. Oxford: Blackwell, 1991.

Ocasio, William (2005) 'The opacity of risk: Language and the culture of safety in NASA's space shuttle program'. W.H. Starbuck, M. Farjoun eds. Organization at the limit: Lessons from the Columbia disaster. Blackwell Publishing, Oxford, 101-121

Quinn, Ryann, \& Worline, Monica (2008) ‘Enabling courageous collective action: Conversations from United Airlines flight 93', Organization Science, 19: 497-516 
Rowlinson, M (2004) 'Challenging the foundations of organization theory', Work, Employment and Society, 18(3): 607-620

Safranski, Rudiger (1998) Martin Heidegger: Between good and evil, Ewald Osers (trans.), Cambridge, Mass.: Harvard University Press.

Sandberg, Jorgen \& Tsoukas, Haridimos (2011) 'Grasping the logic of practice: Theorizing through practical rationality', Academy of Management Review, 36(2):

Snook, Scott A. (2000). Friendly fire: The accidental shoot down of U.S Black Hawks over Northern Iraq. Princeton University Press, Princeton, NJ.

Staehler, Tom (2007) 'How is a phenomenology of fundamental moods possible?' International Journal of Philosophical Studies, 15(3): 415-433.

Strati, A (2007) Sensible knowledge and practice-based learning. Management Learning, 38(1): 61-77

Vaughan, Dianne (1996). The Challenger Launch Decision: Risky Technology, Culture and Deviance at NASA. Chicago, Ill.: University of Chicago Press.

Weick, Karl (1979) The social psychology of organizing (2nd edition). Thousand Oaks, CA: Sage. 
Weick, Karl E. (1988) 'Enacted sensemaking in crisis situations'. Journal of Management Studies, 25(4), 305-17.

Weick, Karl (1993). The collapse of sensemaking in organizations: The Mann Gulch disaster. Administrative Science Quarterly, 38: 628-652.

Weick, Karl (1995) Sensemaking in organizations. Thousand Oaks, CA: Sage.

Weick, Karl (1996). Drop your tools: An allegory for organizational studies. Administrative Science Quarterly, 41(2): 301-313.

Weick, Karl (2003) 'Theory and practice in the real world' in H. Tsoukas and C. Knudsen (Eds.) The Oxford handbook of organization theory. New York: Oxford University Press. 453-475

Weick, Karl (2006) 'Faith, evidence, and action: Better guesses in an unknowable world', Organization Studies, 27: 1723-1736

Weick, Karl (2012) 'Organized sensemaking: A commentary o processes of interpretive work', Human Relations, 65(1): 141-153

Weick, Karl, \& Putnam, Ted (2006) 'Organizing for mindfulness: Eastern wisdom and western knowledge', Journal of Management Inquiry, 15(3): 275-287 
Weick, Karl E., \& Sutcliffe, Kathleen M. (2007) Managing the unexpected: Assuring high performance in an age of complexity. San Francisco: Jossey Bass.

Whiteman, G., and Cooper, W.H. (2011), 'Ecological sensemaking', Academy of Management Journal, 54: 889-911.

Zundel, Mike (2012) Walking to learn. Management Learning

Zundel, Mike and Kokkalis, Panagiotis (2010) Theorizing as engaged practice. Organization Studies, 31(9): 1-19 